Open Access

\title{
Investigating the professional agency of secondary school English teachers in South Korea
}

Wook Namgung $^{1 *}$, Josephine Moate ${ }^{1}$ and Maria Ruohotie-Lyhty ${ }^{2}$

\author{
*Correspondence: ngwook00@ \\ gmail.com \\ ${ }^{1}$ Department of Teacher Education, \\ University of Jyväskylä, 40014 \\ Jyväskylä, Finland \\ Full list of author information is \\ available at the end of the article
}

\begin{abstract}
This qualitative study examines the professional agency of secondary English teachers in Midwestern South Korea. Specifically, it investigates how secondary English teachers in South Korea understand their professional agency and what mediates their professional agency. The ecological approach in this study recognises that agency encompasses both individual and environmental dimensions and is formed through the constant interplay between the individual and the environment. The dataset for this study comprises 15 semi-structured interviews with secondary English teachers in South Korea. The thematic analysis highlights a significant gap between Korean English teachers' espoused agency and realisable agency, as well as three levels of legitimation that teachers have to negotiate. These levels are individual, collegial and sociocultural. The findings from this study suggest that the participating teachers censored their own pedagogical behaviours due to their own sense of inadequacy and in response to structural requirements as well as the external evaluation of parents and high-stakes test scores. This study concludes with implications for English teachers in South Korea, theorisation on teacher agency and future research.
\end{abstract}

Keywords: Professional agency, Legitimacy, Secondary English teacher, Korean education

\section{Introduction}

In South Korea the teaching profession is consistently the most attractive career choice in regular opinion polls for high school graduates due to high job stability and the relatively high salary of teachers (Korean Ministry of Education, 2015a, b), and the intake for teacher education is only a small percentage of all applicants. It is perhaps surprising then that according to the OECD Teaching and Learning International Survey (TALIS) 2013 results, 20\% of Korean secondary teachers reported that they regret becoming a teacher, a very high proportion since the international average is $9 \%$ (OECD [The Organization for Economic Cooperation and Development], 2014). This discrepancy between the high popularity and the low job satisfaction of the teaching profession suggests it is worth investigating the relationship between teacher

(c) The Author(s). 2020 Open Access This article is licensed under a Creative Commons Attribution 4.0 International License, which permits use, sharing, adaptation, distribution and reproduction in any medium or format, as long as you give appropriate credit to the original author(s) and the source, provide a link to the Creative Commons licence, and indicate if changes were made. The images or other third party material in this article are included in the article's Creative Commons licence, unless indicated otherwise in a credit line to the material. If material is not included in the article's Creative Commons licence and your intended use is not permitted by statutory regulation or exceeds the permitted use, you will need to obtain permission directly from the copyright holder. To view a copy of this licence, visit http://creativecommons.org/licenses/by/4.0/. 
professionals and the working conditions of the environment. This relationship has been quite extensively explored in western cultural contexts through the lens of professional agency (Biesta \& Tedder, 2006; Pappa, Moate, Ruohotie-Lyhty, \& Eteläpelto, 2017; Van Lier, 2008), however, it has received little attention within the Korean educational context (Kim, 2013a, b; Yoo, 2015).

Teachers have played an important role in the development of Korea throughout the twentieth century (Kang, 2002; Synott, 2007). During the first decades of Japanese colonisation periods, teachers were tasked with fostering pupils to be obedient and cooperative people for the Japanese Empire (Kim, 2013a, b); subsequently, teachers were tasked with preparing pupils to be suitable workers for the developing nation of South Korea modelled on the competitive, capitalist system of the US. This historical background has arguably encouraged Korean teachers to follow top-down instructions and disrupted the formation of teacher initiative and autonomy. Over time, grassroots level initiatives that had promoted more altruistic forms of education were squeezed out of the increasingly competitive system (Kang, 2002). Successive governments resisted the establishment of a teachers' union that promoted the basic rights of teachers and students because of its anti-governmental stance (Kang, 2009) and teachers have been overly committed to long working hours teaching and doing excessive administrative works (Lee, 2019).

Furthermore, Korean teacher culture has been characterised as defensive and conservative with Korean teachers teaching their subjects and evaluating students' ability in a way that seeks to avoid student and parent complaints (Lee, 2006). Although some Korean teachers brave the trials and errors of implementing innovations in teaching or assessment, external criticism, whether from parents or the municipal education office, often carries such weight that Korean teachers and school administrators have been hesitant to put new ideas into practice (Kim, 2003). It is this relationship between individual teachers and their work environment that is the focal interest of this study and in particular "the capacity of people [in this instance, Korean secondary school English teachers] to act purposefully and reflectively on their world" (Rogers \& Wetzel, 2013, p. 63).

The current study focuses on the professional agency of teachers. Professional agency has been investigated in a variety of educational fields to date with studies targeting teachers from different educational levels including vocational school (Vähäsantanen, 2013), primary school (Haneda \& Sherman, 2018; Pappa et al., 2017), and pre-service teacher education (Kayi-Aydar, 2015). Research on the professional agency of teachers has also addressed a wide range of curricular concerns, including the foreign language mediation of education (Moate, 2014), the agency of language teachers (Ruohotie-Lyhty, 2013) and teachers' capacity to develop the curriculum in school (Priestley \& Drew, 2019; Priestley, Edwards, Priestley, \& Miller, 2012). In the following section, we outline key developments in conceptualisations of agency in order to illustrate how an ecological exploration of professional agency extends conventional conceptualisations of agency.

\section{Theoretical framework}

\section{Agency}

Agency has been a popular research topic across disciplines, such as the social sciences and education in this post-modern era that favours human creativity and autonomy in 
personal and professional life. Despite the multiplicity of research, no shared definition of agency had been agreed (Eteläpelto, Vähäsantanen, Hökkä, \& Paloniemi, 2013) and the crucial individual-environment relationship has been formulated in significantly different ways perhaps due to a tendency to simplify the capacity of actors for autonomous action and to over-emphasise an individualistic view (Priestley, Biesta, \& Robinson, 2015). Giddens (1984), for example, defines agency as the intentional action of an individual responding to problematic situations or autonomously acting independent of social constraints (Biesta \& Tedder, 2006). A contrasting perspective emphasises agency as a socioculturally mediated capacity to act (Ahearn, 2001), a view which suggests that individual wants, values and priorities of decision-making are socially determined. In contrast to this overly-socialised view of agency as a capacity shaped and moulded by the social context, Archer advocates a dualistic concept of agency that recognises the way in which humans form society through their activities, but they are also shaped by it. She points out that there is always an interplay between structure and agency as distinctive sets of causal powers in reality (Archer, 2000).

Emirbayer and Mische's (1998) conceptualisation of agency acknowledges the temporally embedded process of social engagement that is informed by the past as well as oriented toward the future as a projective capacity to imagine alternative possibilities within the conditions of the present. For Emirbayer and Mische (1998) agency emerges from the interaction between individual capacity and the environment. Biesta and Tedder (2006) also define agency as a transaction with the environment thus emphasising the intrinsic relationship between agency and the environment in which agency is realised and realisable.

As previous studies point out, it seems to be difficult to analyse the complexity of agency and the interplay among variant components of agency with extreme versions of the structure-agency dichotomy. It is perhaps helpful to recognise that agency is not only an individual's voluntary control over behaviour but also a social event that does not take place in a void or in an empty wilderness (Eteläpelto et al., 2013; Lipponen \& Kumpulainen, 2011). In Fig. 1, both individual and environmental dimensions are encompassed within the definition of agency. The individual dimension draws on Emirbayer and Mische's (1998) chordal triad of an individual's past, future and present manifested as the iterational, projective, and practical-evaluative aspects. The environmental dimension is an umbrella term to indicate different kinds of social structures that can affect the formulation of agency through the range of affordances and constraints that belong to sociocultural environments. The dotted line between the individual and environmental dimensions indicates the distinction between these two dimensions, without suggesting that they can be separated. It is the overall ecology and ongoing interplay between the individual and environmental dimensions of agency that are of particular interest in the present study.

\section{Interplay between the individual and the environment in educational contexts}

The interplay between the individual and environment in educational contexts has been conceptualised in a number of ways. Van Lier (2000) has contributed to the notion of agency by drawing on an ecological perspective and emphasising the significance of affordance. Affordance acknowledges the properties of the environment and the active 


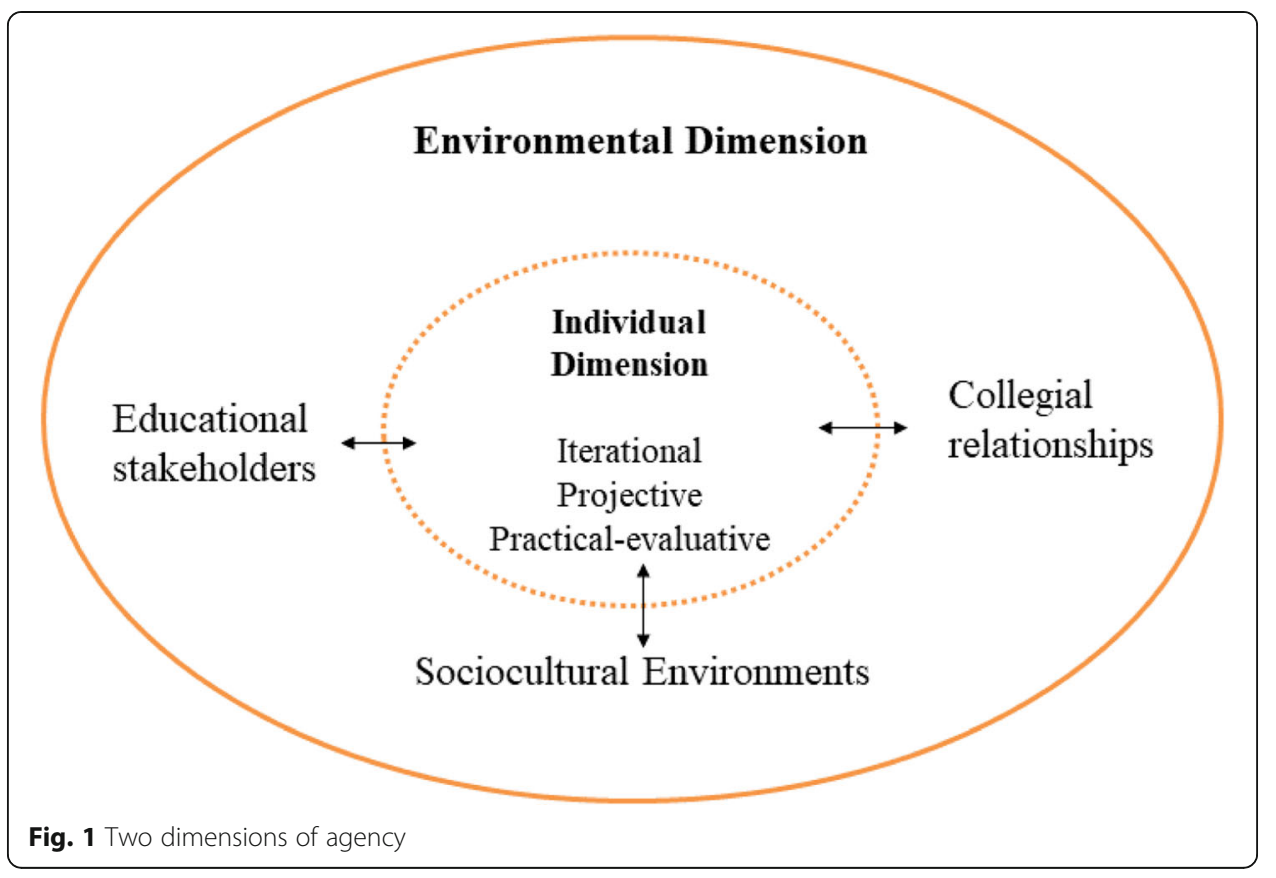

responsiveness of a learner, for example, whether a language learner is able to use resources that are offered (Sun, 2019). Van Lier (2004) notes that an individual can be agentic when choosing or refusing to use a resource that is available within the environment. This ecological perspective, however, acknowledges the reciprocal and dynamic nature of the individual-environment relationship in that both individuals and the environment are sensitive and responsive to one another. Ruohotie-Lyhty and Moate (2015) in their study of pre-service teachers have described this relationship in terms of proactive and reactive agency highlighting how teachers can experience their environment as a resource for or limitation to development. More recently, Moate and Ruohotie-Lyhty (Moate, J., \& Ruohotie-Lyhty, M.: Identity and Agency Development in a CLIL-based Teacher Education Programme, forthcoming) have highlighted the ongoing dynamic of the individual-environment relationship and the way in which this forms the overall ecology of teacher development.

The interplay between individual and environment can also be examined with the notion of legitimacy, a notion that recognises the complications of power and authority, as well as the (im) balance of relationships. A stance, action or organisation may be legally legitimate, yet this does not automatically bestow social legitimacy. Moreover, legitimating powers can work almost invisibly, for example, by maintaining the existing status quo, assisting in the reproduction of inequality in education (Apple, 2012) or cloaking cultural capital as a neutral asset and overlooking the implicit favouring of those who have already acquired linguistic and social competencies (Apple, 2004). In this way, legitimacy can be seen as a self-serving concept in that as it supports selecting others, it simultaneously reinforces itself (Arnot, 2006). Strict national curricula and standardised tests that stratify students in competitive educational environments, for example, can lead both to increasing privatisation and increasing centralisation of control over official knowledge to "educational apartheid" (Apple, 2004) with students and teachers in a mechanism of objectification (Foucault, 
2012). Within this complex ecology of interconnecting and competing interests, teachers have to work out their individual commitments and pedagogical practices.

Legitimation has been a useful notion in the field of applied linguistics. Although all languages might be linguistically equal, they are not equal as forms of sociocultural power since speakers of different languages are afforded different levels or forms of social power and authority, for example, whether they are considered a legitimate lingua franca or not. The issue of linguistic legitimacy is more severe within a single language. If one form of a speech among others imposes itself as the only legitimate one, the other different class or regional dialects have to be measured against the legitimate language (Bourdieu, 1977). The dominant form of speech in the language becomes the norm against the other modes of expression. The legitimate linguistic practices emphasise the significance of the environment since legitimation is not intrinsic to a language but rather contextually and socially constructed and dependent on a variety of ecological factors (Ennser-Kananen, 2018).

Individuals, however, are often unaware of the forces and values that inform and guide their actions (Savaya \& Gardner, 2012), and significant discrepancies can exist between the espoused theories that teachers believe guide their behaviours and the theory-in-use reflected in their behaviours in practice (Argyris \& Schon, 1974; Jones, 2009). This study defines espoused agency as that which teachers would like to exercise in the ideal ecological affordances and realisable agency as that which teachers can exercise through various types of legitimation within the particular conditions of their environment. In the present study on secondary English teachers' professional agency in South Korea, we are particularly interested in the interplay between the individual teachers and the conditions of their working environment, and the implications this has for the realisation of their professional agency.

This complex and ecological conceptualisation of agency, therefore, suggests an important distinction between agency and autonomy. Whilst agency entails multidimensional attributes that include intrapersonal and environmental factors (Larsen-Freeman, D., 2019), autonomy focuses primarily on an individual's independent and free decision for action. Moreover, this conceptualisation does not equate teacher agency with teacher autonomy as teachers granted autonomy do not necessarily achieve agency as they, for instance, habitually reproduce past patterns of behaviour or as they may lack cognitive and relational resources (Priestley et al., 2015). This study recognises that research on the professional agency of teachers is not just a matter of examining individual teachers' capacity to act but also an examination of the environment that influences the formation and realisation of teacher agency and the way in which the overall ecology for teacher agency develops (Priestley \& Drew, 2019).

\section{Context for the research}

Educational policies in South Korea have long sought to globalise and develop an educational system that produces an efficient workforce able to meet the demands of an industrialised high-tech society (Kang, 2002; Synott, 2007) and English has been considered the most important foreign language for a variety of historical and sociocultural reasons. Both the government and individuals endorse globalisation and English education through top-down and bottom-up efforts (Song, 2016). The Korean administration implemented a policy of so-called "English Village" where students can experience 
English-dominant culture all around the environment to satisfy Korean people's aspiration for learning English. In spite of the huge financial investment to establish English villages around Korea, this investment has resulted in a huge deficit and inefficiency (Hong, 2012). A series of English educational policies such as English immersion education, Teaching English in English (TEE), and National English Ability Test (NEAT) have also been introduced but seem to have contributed little improvement to English education in South Korea. In addition to governmental initiatives, Korean people invest around 79,000 Korean won (about 60 Euros) a month in private English studies (Statistics Korea, 2018) and many Korean people spend a lot of money sending children to English-speaking countries to improve their English communication skills (Kim, 2017). In the competitive social atmosphere of South Korea, a private education market is well established and benefits from stimulating parents' fear of their children being left behind without the assistance of private education.

Meanwhile, a new English national curriculum has been developed and implemented in primary school grade 3 4, lower secondary school grade 1 and upper secondary school grade 1 from 2018. This new "competency-oriented curriculum" (Lee, 2016) emphasises key competencies in anticipation of societal developments including English communication competency, self-management competency, community competency and knowledge-information processing competency (Korean Ministry of Education, 2015a, 2015b). English subject teachers are required to be fully aware of these competencies and expected to design their English classes that enable students to develop the competencies through various activities. Teachers need to consider reorganising their own English curriculum as the new English national curriculum encourages teacher agency in making their own curriculum in order to promote diversity and creativity. In particular, the Korean government has implemented a free learning semester in every Korean lower secondary school since 2016, in which the school does not have any regular paper tests such as mid-term and final exams and encourages teachers to employ process-oriented evaluation (Lee, 2018). The free learning semester has been extended from one semester to one academic year in some lower secondary schools since 2018.

These government initiatives have arguably offered new opportunities for teacher agency in educational activities as well as curriculum organisation. Nevertheless, changing the dynamics of the well-established relationship between the working environment and teachers' professional agency is complex and challenging (Priestley et al., 2012).

\section{Research questions}

This study aims to examine how secondary English subject teachers in South Korea exercise their own professional agency within the context of English language education. The particular research questions are:

(1) How do secondary English teachers in South Korea understand their professional agency?

(2) What mediates the professional agency of South Korean English teachers?

\section{Methodology}

This qualitative study is based on interviews with 15 secondary English teachers in South Korea. The participants include eight lower secondary school teachers and seven 
upper secondary school teachers who work in Chungnam Province, South Korean Midwestern area. The first author works at the same municipality and the participants were invited through local teacher networks (Tracy, 2012). More details on the participating teachers are provided in Table 1.

\section{Research design and data collection}

Investigating the professional agency of secondary English teachers in South Korea requires that the actual voices of the participants are part of the study. The semi-structured interviews used in this study were designed to provide a space for the participants to share their experiences without imposing a structure on the narrative and allow the participants to expand on their experiences within a shared frame (Holloway \& Jefferson, 2000) as the first author also acted as the interviewer in the study. The questions were open-ended and focused on their temporal experiences including past, present and future as well as their knowledge and opinion with regard to practical English education, for example:

- Why did you decide to become a secondary English teacher?

- What type of English teacher do you wish to become?

- What supports or enables you to teach as you think it is desirable or appropriate?

- What prevents you from exercising your professional agency in teaching English?

The data were collected from July to August 2018. Participants were informed about the methods, purpose of the study and ethical commitments prior to the interviews, whilst an informed consent form was signed at the beginning of interviews. The interviews were recorded on two devices and stored in a computer as well as on a

Table 1 Information on participants

\begin{tabular}{|c|c|c|c|c|c|}
\hline Teacher & Sex & Level of Present School & Career trajectory (yrs) & Years of teaching career (yrs) & Job Security \\
\hline 1 & $F$ & Lower secondary & $\begin{array}{l}\text { Lower: } 6 \\
\text { Upper: } 7\end{array}$ & 13 & Permanent \\
\hline 2 & $\mathrm{~F}$ & Lower secondary & $\begin{array}{l}\text { Lower: } 2.5 \\
\text { Upper: } 0.5\end{array}$ & 3 & Temporary \\
\hline 3 & M & Lower secondary & Lower: 5 & 5 & Permanent \\
\hline 4 & M & Lower secondary & $\begin{array}{l}\text { Lower: } 4 \\
\text { Upper: } 7\end{array}$ & 11 & Permanent \\
\hline 5 & $\mathrm{~F}$ & Lower secondary & Lower: 30 & 30 & Permanent \\
\hline 6 & $F$ & Lower secondary & Lower: 30 & 30 & Permanent \\
\hline 7 & M & Lower secondary & $\begin{array}{l}\text { Lower: } 4.5 \\
\text { Upper: } 5\end{array}$ & 9.5 & Temporary \\
\hline 8 & $\mathrm{~F}$ & Lower secondary & Lower: 6 & 6 & Permanent \\
\hline 9 & M & Upper secondary & Upper: 13 & 13 & Permanent \\
\hline 10 & M & Upper secondary & Upper: 10 & 10 & Permanent \\
\hline 11 & M & Upper secondary & Upper: 1 & 1 & Permanent \\
\hline 12 & $\mathrm{~F}$ & Upper secondary & Upper: 22.5 & 22.5 & Permanent \\
\hline 13 & M & Upper secondary & $\begin{array}{l}\text { Lower: } 1 \\
\text { Upper: } 6\end{array}$ & 7 & Permanent \\
\hline 14 & M & Upper secondary & Upper: 30 & 30 & Permanent \\
\hline 15 & $\mathrm{~F}$ & Upper secondary & Upper: 3 & 3 & Permanent \\
\hline
\end{tabular}


password-protected external hard drive for secure data protection. The collected data have been anonymised.

\section{Data analysis}

The interviews lasted from 1 hour to about 1 hour and 40 minutes and were transcribed verbatim (see the Additional file 1). An iterative form of thematic analysis (Tracy, 2012) was used to elicit the critical points in the data with regard to the teachers' professional agency and the interplay between the individual teachers and their work environment. Thematic analysis is a useful method for a qualitative research for identifying, analysing and reporting experiences, meanings and reality of participants within data (Braun \& Clarke, 2006). Through multiple re-readings of the transcripts, the data were coded with descriptive codes before patterns within the data were identified. The final stage of analysis was based on the critical dialogue between the professional agency as a theoretical construct and professional agency as a lived experience. The analytical process was conducted manually rather than using qualitative data analysis software. An example of how the data were analysed is presented in Table 2.

\section{Findings}

As an investigation into the professional agency of secondary English teachers in South Korea, this study is particularly interested in the dynamic interplay between individual teachers and their ecological environments. The findings suggest that legitimacy of professional agency is particularly significant in relation to the individual self, collegial relationship, and the wider sociocultural environment as outlined in more detail in the following section.

\section{Individual legitimation}

At the heart of professional agency is the individual's relationship with his or her self. A striking finding in this study was the way in which individual teachers censored their own pedagogical competency by drawing on individual and ecological factors. Although the participants recognised that they are supposed to take an agentic position in curriculum design according to a new curriculum policy, their doubt in their own competency and lack of confidence, as well as remaining structural constraints, inhibited their agency as the following extracts indicate:

Table 2 Steps of data analysis

\begin{tabular}{|c|c|c|}
\hline Steps & Actions taken & Examples \\
\hline 1st & Coding the raw data with descriptive codes & $\begin{array}{l}\text { Parents' complaints about KETs' teaching materials } \\
\text { and methods } \\
\text { Parents' requests for KETs' English teaching related } \\
\text { to KSAT }\end{array}$ \\
\hline 2nd & $\begin{array}{l}\text { Grouping codes and naming basic } \\
\text { themes by identifying patterns }\end{array}$ & Parental complaint \\
\hline $3 \mathrm{rd}$ & Identifying illustrative excerpts & $\begin{array}{l}\text { 'I started at that point when I was a novice teacher } \\
\text { but the goal has been changed after facing lots of } \\
\text { complaints. At last, I came to design the assessment } \\
\text { and class at a level where parents and students don't } \\
\text { complain and implemented them in that way.' } \\
\text { (Teacher 13) }\end{array}$ \\
\hline 4th & Identifying key themes & 'Parental complaint' under 'Sociocultural legitimation' \\
\hline
\end{tabular}


I think I use the textbooks in about 90\% of my English class. Even though it is recommended to reorganise the curriculum and include the materials from outside of textbooks and also the importance of textbooks is being decreased these days, I still depend highly on textbooks because I think I'm not enough to reorganise the curriculum with the materials outside of textbooks. (Teacher 2)

If we don't have textbooks, it's not socially allowed 100\% for teachers to design the curriculum by themselves and teachers lack time to design the curriculum without textbooks and we have a lot of other paperwork so we depend on the textbooks... Many complicated factors affect us, which leads us to make classes limited to textbooks. As a new national curriculum was implemented, that kind of atmosphere seems to have changed a lot and I also began to aspire to get a little more away from textbooks. (Teacher 8)

All the lower secondary English teachers interviewed articulated that they depend on textbooks in about $80 \%$ of their English classes. From their perspective, textbooks were considered as neutral, pre-given and positivistic, 'safe' options that are part of a wellestablished pedagogical practice, even if they did not correspond with current policy and even the aspirations of the teachers. It is also noticeable in Teacher 8's excerpt that the implementation of a new national curriculum encouraging English teachers to be more agentic stimulated them to try taking more agentic attitude on selecting teaching materials. This shows that the appropriately framed curricular specification might play a powerful role in enabling English teachers' espoused agency (Priestley et al., 2015). The denial of individual legitimacy was also present, however, as the participants considered the four skills of reading, writing, listening, and speaking. As Teacher 3 explained:

I guess that the four skills of practical English are the most important rather than English for academic scores. The ideal English teacher is to help improve practical English skills to be good at the four skills ... ... I'm a very deficient teacher and it's never-ending to study a foreign language in terms of its nature. So I should study more. That sometimes makes me unsure (of my English skills). In particular, this is applied to many English teachers, in the speaking part, when I teach speaking, I sometimes think, "Am I speaking in the right way?". That's the most challenging part of the four skills. (Teacher 3)

Teacher 3 has the espoused agency to help students improve the four skills in a practical way but it is inhibited by his doubt on his own English speaking ability. The selfdoubt profoundly connects with the ideology of Standard English, which is the belief that there is a single authentic version of the language and that other variants of the language are dialects that reflect improper ways of speaking (Schulzke, 2014). As an ideology that is prevalent among Korean secondary English teachers, this belief legitimises native speakers from core English-speaking countries whilst Korean secondary English teachers experience their own English speaking as illegitimate. This stance with regard to individual legitimation reflects the proposition that language is not only an instrument of communication or even of knowledge, but also an instrument of power that can empower or undermine (Bourdieu, 1977). 
In practice, the participants' distrust of their own competency to teach these skills, in particular speaking, limited their freedom to design student assessment and directed their professional agency in ways that ran counter to their own ideals. The participants admitted to focusing assessment on student accuracy rather than fluency to limit the amount of speaking in English classes. Some participants tried to reconcile the disjuncture between their espoused belief and assessment practice by acknowledging that they wished to include more non-assessed activities to develop students' fluency in every English skill. In these examples, the participants' professional agency was exercised to compensate for their personal insecurity and contradictory practice rather than to develop English language education. Many of the teachers in the study were aware of what was expected of them as English teachers within the Korean education system, yet the lack of a legitimate sense of self seemed to compromise the teachers' agentic experience.

\section{Collegial legitimation}

In South Korea, English teachers that are assigned to teach in the same grade at a secondary school should reach collegial consensus with regard to what is assessed. In other words, fellow English teachers assigned in a same grade are expected to organise the same types of assessment and set the same test range. Even though collaboration with colleagues may initiate a variety of pedagogical benefits, this structural requirement has significant implications for the kind of teaching materials and approaches that can be legitimately adopted in English classes, as highlighted in the extracts below:

I can teach according to the teaching contents but because I need to follow normreferenced assessment and must make my assessment criteria consistent with fellow teachers teaching other classes in the same grade, it really limits my teaching. I wish I could assess my classes based on what I taught them... If the assessment is restricted, it is followed by the limit of teaching in class. I can't teach what I want and bring richer materials into my English classes. (Teacher 5)

It's not easy to reorganise the curriculum. As I told you before, if I take charge of one grade by myself, it would be easy to reorganise it because I can do it as I want... In this large school, three English teachers teach 3rd grade. So we can't help having classes with textbooks, making questions only within textbooks, no prior learning, of course, I agree with that, anyway it's sad that only textbook-oriented classes are possible with three English teachers in same grade. (Teacher 6)

The structural constraints that English teachers in the same grade should make their assessment plan in consensus hardly allow them to take agentic actions in deciding the content and pedagogy of English curriculum as well as its assessment. They espouse to assess students based on what they actually teach in class but have to consider realistically what other colleagues teach in different classes because all of the students in a year group take the same paper tests. Within this setting, idiosyncratic pedagogical ideas and espoused agency on what to teach and what to assess are easily compromised through the process of collegial consensus. 
The upper secondary English teachers appeared to be under greater pressure than the lower secondary counterparts in making the teaching materials and assessment consistent due to the critical importance of academic scores for university admission. If more than two teachers are involved in teaching students within the same grade, they always need to consider how the other teachers utilise the teaching materials and assessment.

... There is the problem with teachers' cooperation. We all think differently and if anyone wants to try something, the teacher can't implement it by oneself. Because two or three teachers are tied in a grade, any teaching or assessment plan will not be realised if just one teacher doesn't agree with it. I don't care to be compared with other teachers, but it's really difficult to make changes when working in a team. If any fellow teacher doesn't move or any teacher next to me is less innovative than me, the game is over ... (Teacher 10)

I seem to pay a lot of attention to students' assessment. I don't want to hear that students ruined the exam because of me so I'm sensitive to their assessment. What should I do if my class progress is slower than other teachers' classes? This year, it's okay to progress with my class slower than last year but I'm pressured with the class progress and there are three English teachers in a grade so we're pressured to make the class progress in consensus. Why does that teacher teach this but my teacher doesn't teach it? What if that comes in the exam but I didn't mention that? This kind of issue I have. Everyone seems to focus exclusively on the English exam because the high school records are important. (Teacher 11)

Any teaching methods and assessment types require the approval of each fellow English teacher working within the same grade in order to be considered legitimate. Even if the teachers recognise that individual students have their own learning styles and wish to be pedagogically innovative, the participants in this study face the dilemma of how to work within the given structures of collegial collaboration. If a teacher wishes to be pedagogically innovative, he or she faces the inevitable task of first having to persuade colleagues and risk being the cause of dissatisfaction for the entire grade. It is perhaps unsurprising that although the participants in this study shared idiosyncratic pedagogical perspectives, they could not help realising a form of agency that ran counter to their own pedagogical preferences. This suggests that collegial legitimation can play a critical role in inhibiting their teacher agency if it is utilised as a monitoring structure to decide what is legitimate in teaching English.

\section{Sociocultural legitimation}

Korean parents tend to pay careful attention to students' numerical academic scores as they can be used to stratify students in school and for entrance to the next stage of education. This kind of social atmosphere demands neutral and positivistic assessment which is deemed fair and beyond reproach. For the participants in this study, this keen interest of parents appears to influence how secondary 
English teachers actually teach English, particularly for teachers working in the upper secondary school:

At the beginning of my teaching career, all of my worries were to improve students' English skills and to help them feel what English is about. I started at that point when I was a novice teacher but the goal has changed after facing lots of complaints. Lately, I have designed the assessment and class at a level where parents and students don't complain and implemented them in that way. That [Parents' and students' responses] really affected them [the assessment and class]. (Teacher13)

Teacher 13's espoused agency was to improve students' English skills and to help them feel what English is about but it was inhibited by students' and parents' complaints that required his class to be more oriented towards KSAT preparations. For the participants in this study, sociocultural legitimation can differ dramatically according to the context where the teachers work with English teachers working at high performing schools experiencing greater pressure than those working at low performing schools. The former needs to be more sensitive to the responses of other educational stakeholders including parents and students. Teachers have to pay more attention to the way they teach or assess in order to maintain or even further raise the high attainment in standardised examinations such as KSAT. However, as teachers working in low performing schools do not face such pressure or scrutiny, they can more easily design their teaching and assessment in the way they want.

If I work at a girls' high school now, I could teach my class as I wish. But in the past, the English classes at the girls' high school couldn't be separated from KSAT, I felt quite burdened by it so I couldn't teach as much as I wished ... . On the other hand, I don't have any burden at the present school. I do teach as I wish and don't have any mental restriction. (Teacher 9)

The girls' high school in the above excerpt has a reputation as a high achieving upper secondary school in the local municipality. Teacher 9 described in the excerpt how his hopes and intentions, which are his espoused agency as an individual, were inhibited by the sociocultural expectations of the environment. Structural expectations that legitimised particular practices pressured this teacher to teach to the test in this upper secondary school. This pressure disappeared, however, when he began to teach in his present school, a vocational high school with low attainment. In this new environment, Teacher 9 was able to return to his original hopes and intentions as a teacher.

For the participants in this study, their professional agency appears to be significantly influenced by sociocultural considerations such as external evaluations, parental intervention and the reputation of the school that legitimise or deny the validity of pedagogical practices. Although the participants consistently hoped to improve students' English skills and help them gain a real taste for learning English through their iterative experiences, this espoused agency was constrained by complaints from parents and students. As a result, the realisable agency of these teachers was bound to pedagogical practices that they had not envisaged for themselves but which were considered legitimate within the sociocultural setting. 


\section{Discussion}

The two research questions underpinning this study address how secondary English teachers in South Korea understand their professional agency and what mediates their teacher agency. This pioneering research on teacher agency within the Korean context highlights the way in which 'legitimacy' plays a pivotal role in mediating the teacher agency. This provides a new lens for making sense of teacher experiences in general as well as in the Korean context. Furthermore, on a teacher education level it can draw attention to the responsibilities of educational leadership as well as educating teachers to be aware of the professional responsibilities they have pertaining to their own development, collegial relationships and the sociocultural environment.

The findings indicate that the individual aspirations and intentions of secondary English teachers in South Korea are subject to significant pressures from individual teacher selves, collegial relationships and the wider sociocultural setting. With regard to individual legitimation, teachers censor their own pedagogical behaviours using Standard English ideology that they have seemingly internalised as well as an exacerbated sense of their own inadequacy in linguistic and pedagogical terms. Withholding individual legitimation seems to redirect the professional agency of teachers towards compensatory actions that might conflict with their espoused ideals but provide some kind of reassurance.

Collegial legitimation refers to the structural requirement that colleagues monitor other teachers' pedagogical approaches and methods of assessment. Agency is not inhered in a person but is relational in that it persists only through the constant interaction with others (Larsen-Freeman, D., 2019). Although the relational characteristic of agency often enables teachers to achieve a variety of pedagogical benefits, the monolithic and obligatory consensus of assessment hardly allows English teachers to achieve the heterogeneous and idiosyncratic espoused agency. The collegial consensus obligated by educational policies means that if a teacher hopes to trial a new pedagogical approach, this has to be a public trial. It is perhaps unsurprising that many of the participants exercised their professional agency by trying to reconcile the contradiction between their espoused hopes to provide a good language education and their realised practices of maintaining the established status quo. Once they have to teach English with other fellow teachers in a same grade, they become trapped in the mechanism of objectification and they judge each other's assessment types as well as teaching materials for its consensus in the mechanism. The mechanism of objectification between the collegial relationships at school serves to legitimise secondary English teachers' pedagogical methods and assessment.

Finally, with regard to sociocultural legitimation, the teachers' professional agency was legitimised through the external evaluation of parents and high-stakes test scores. This form of legitimation most keenly impinged on the professional agency of teachers working in academically successful schools. The higher the stakes for the student exams are, the greater the pressure on teachers to exercise their professional agency is within the established constraints of the demand to pass the exams, even at the expense of the mandated curriculum that purportedly favours the teacher agency. It appears as though the examination holds not only students but also secondary English teachers in the mechanism of objectification (Foucault, 2012). Moreover, these examinations favour the cultural capital of academically successful social groups so teachers become part of the reinforcing mechanisms of cultural capital (Song, 2016). 
A key finding in this study is the disjuncture between the teachers' espoused agency that they wish to exercise and the realisable agency that is legitimised by individual and environmental factors. For the participants whether their agency is considered legitimate or not significantly influenced the way in which professional agency was exercised, whether proactively or reactively (Ruohotie-Lyhty \& Moate, 2015). This finding suggests that the process of legitimation is a keen mediator between the teachers' espoused and realisable agency. As in other sociocultural contexts, the professional agency of individual teachers is held in tension with the working conditions and established structures (Pappa et al., 2017; Vähäsantanen, 2013), yet here legitimation more keenly mediates the interplay between the individual and environment provides an important insight.

As Fig. 2 indicates, Korean English teachers have clear ideas and understanding of the teacher type that they would like to be, the pedagogical practices they would like to incorporate and the hopes they have for their students' learning experiences. The inconsistencies between what is espoused and what is realised correspond with findings in other contexts as well (Priestley et al., 2012). In this study, however, it is not only the gap between what is espoused and what is realised, but Korean English teachers also have to contend with three different levels of legitimation: individual, collegial and sociocultural. Each level raises a different kind of question: Am I good enough? Will my colleagues agree? Is this appropriate for the wider community? It is perhaps unsurprising that the enacted agency of Korean English teachers is sometimes significantly different from their espoused agency.

The invisible and obscure nature of legitimacy can have a powerful impact on teacher agency (Apple, 2004). It is hoped that by drawing attention to the hidden ideology and power relations surrounding English education in Korea secondary English teachers can be aware of the legitimacy challenges they face. Awareness is arguably an important practical-evaluative consideration that can challenge the potency of earlier iterational experiences that reinforce existing pedagogical ways by undermining the potential projective considerations that can develop new approaches to the development of English education (Emirbayer \& Mische, 1998). In this study, the belief in Standard English ideology, for example, appears to undermine the legitimacy of individual teachers' practices. If this ideology is challenged by individual teachers and especially within the wider community, professional agency can be exercised in developing the expression of Korean identities and values as well as English competency rather than being subordinated to a myth that sustains itself at the expense of others. Legitimacy itself does not connote to negativity but implies value neutrality. We argue that individual, collegial and sociocultural legitimation can play a positive and effective role for English teachers to achieve their professional agency in more educational affordances such as

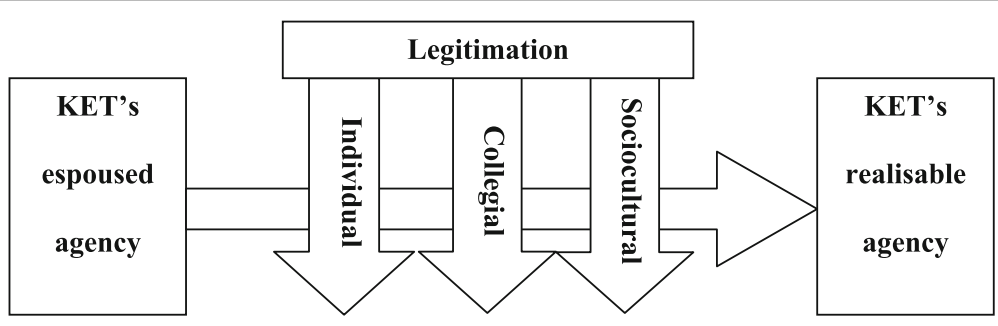

Fig. 2 The mediation process of legitimation between KET's espoused and realisable agency 
educational policies to encourage teacher agency, supportive school leadership and social trust. It is the active interplay between individual teachers and the environment that legitimises or undermines teacher agency.

\section{Conclusion}

This study suggests that even when an individual teacher's professional agency is compatible with the ideals of educational structure, professional agency is always in relation to a complex dynamic system and requires a specific temporal and spatial situation in order to flourish. (Larsen-Freeman, D., 2019). It highlights that teacher agency cannot be achieved in a laissez-faire environment but it is formulated in the interplay between individual teachers and the ecological environments such as educational policy support, proper in-service teacher education and autonomous collegial collaboration.

Earlier theorisations of agency as something that is achieved in specific temporal and relational circumstances (Eteläpelto et al., 2013; Larsen-Freeman, D., 2019; Priestley et al., 2015) gain extra potency in this research. Whilst earlier research has focused on what resources and hampers the development and exercise of professional agency (Lasky, 2005; Lipponen \& Kumpulainen, 2011; Pappa et al., 2017), the concept of 'legitimation' in this study introduces another consideration to the interplay between individual teachers and the conditions of their environment. For the teachers in this study the legitimacy they experienced as English language teachers and teacher professionals profoundly influenced the orientation of their professional agency, whether to manage within given constraints or to attempt to work in a way that aligned with their beliefs regarding good English pedagogy. Moreover, the levels of legitimation suggest the importance of community as a key constituent in the exercise of professional agency. We argue that this concept of 'legitimation' can provide a new lens to reach a broader awareness of agency and contribute to the literature on the development of teacher agency.

There are several limitations of this study. First, the data collection was in one specific region, Chungnam Province in South Korea. A greater number of participants from different regions would provide greater insight into secondary English teachers' professional agency in South Korea and might introduce other aspects of legitimation that affect them. We also recognise that although interviews are often used to gain deep understanding of teachers' professional agency, future research could include other methods such as observations, focus group interviews and case studies to examine the exercise and legitimation of teachers' professional agency from an ecological perspective, not only individual phenomenon. It is hoped, however, that the research reported here takes a pioneering role in a new and meaningful area of educational research area in South Korea.

\section{Supplementary information}

Supplementary information accompanies this paper at https://doi.org/10.1186/s40862-020-00083-1.

Additional file 1. Transcription. 


\section{Authors' contributions}

All three authors have participated in designing, directing and coordinating this research. Wook Namgung, the first author, carried out collecting and analysing the data and drafted the manuscript. Josephine Moate, the second author, assisted in drafting the manuscript and contributed to this study in a variety of ways such as providing reference materials, insightful suggestions and constructive feedback. Maria Ruohotie-Lyhty, the third author, provided a lot of insightful suggestions and constructive feedback on the manuscript during the entire research period. The authors read and approved the final manuscript.

\section{Authors' information}

Wook Namgung is a doctoral candidate at the Department of Teacher Education at the University of Jyväskylä, Finland. His doctoral dissertation focuses on the professional agency of secondary English teachers in South Korea. Dr. Josephine Moate is a Senior Lecturer in education at the Department of Teacher Education at the University of Jyväskylä, Finland. Her research interests include teacher development as well as the role of language in and across education. E-mail: josephine.m.moate@jyu.fi

Dr. Maria Ruohotie-Lyhty is a Senior Lecturer in applied linguistics at the Department of Language and Communication Studies at the University of Jyväskylä, Finland. Her research is broadly situated in the area of identity, agency and emotions in language learning and teaching. E-mail: maria.ruohotie-lyhty@jyu.fi

\section{Funding}

This research did not receive any specific grant from funding agencies in the public, commercial, or not-for-profit sectors.

\section{Availability of data and materials}

Some of the data have been already shared in the interview excerpts of this article. However, the whole data will not be shared because they encompass quite a large amount of data and are saved in a Korean word-processing programme.

\section{Competing interests}

The authors declare that they have no competing interests.

\section{Author details}

${ }^{1}$ Department of Teacher Education, University of Jyväskylä, 40014 Jyväskylä, Finland. ${ }^{2}$ Department of Language and Communication Studies, University of Jyväskylä, Jyväskylä, Finland.

Received: 7 November 2019 Accepted: 17 March 2020

Published online: 09 April 2020

\section{References}

Ahearn, L. M. (2001). Language and agency. Annual Review of Anthropology, 30(1), 109-137.

Apple, M. W. (2004). Ideology and curriculum. Abingdon and New York: Routledge.

Apple, M. W. (2012). Education and power. Abingdon and New York: Routledge.

Archer, M. (2000). Being human: The problem of agency. Cambridge: Cambridge University Press.

Argyris, C., \& Schon, D. A. (1974). Theory in practice: Increasing professional effectiveness. San Francisco: Jossey-Bass.

Arnot, M. (2006). Retrieving the ideological past. In L. Weis, C. McCarthy, \& G. Dimitriadis (Eds.), Ideology, curriculum, and the new sociology of education: Revisiting the work of Michael Apple (pp. 17-36). New York and London: Routledge.

Biesta, G., \& Tedder, M. (2006). How is agency possible? Towards an ecological understanding of agency-as-achievement. In Learning lives: Learning, identity, and agency in the life course.

Bourdieu, P. (1977). The economics of linguistic exchanges. Information (International Social Science Council), 16(6), 645-668.

Braun, V., \& Clarke, V. (2006). Using thematic analysis in psychology. Qualitative Research in Psychology, 3(2), 77-101 https://doi. org/10.1191/1478088706qp0630a.

Emirbayer, M., \& Mische, A. (1998). What is agency? American Journal of Sociology, 103(4), 962-1023.

Ennser-Kananen, J. (2018). That German Stuff: Negotiating linguistic legitimacy in a foreign language classroom.

Eteläpelto, A., Vähäsantanen, K., Hökkä, P., \& Paloniemi, S. (2013). What is agency? Conceptualizing professional agency at work. Educational Research Review, 10, 45-65.

Foucault, M. (2012). Discipline and punish: The birth of the prison Vintage.

Giddens, A. (1984). The constitution of society. Berkeley: University of California Press.

Haneda, M., \& Sherman, B. (2018). ESL teachers' acting Agentively through job crafting. Journal of Language, Identity \& Education, 17(6), 402-415.

Hollway, W., \& Jefferson, T. (2000). Doing qualitative research differently. London: SAGE Publications Ltd.

Hong, Y. D. (2012). The downfall of the first English village in Korea, Ansan English Village Retrieved from http://www.hani.co.kr/ arti/society/area/559203.html.

Jones, A. (2009). Generic attributes as espoused theory: The importance of context. Higher Education, 58(2), 175-191.

Kang, H. R. (2009). Teachers, praxis, and minjung. In The Routledge international handbook of critical education (p. 409).

Kang, S. W. (2002). Democracy and human rights education in South Korea. Comparative Education, 38(3), 315-325.

Kayi-Aydar, H. (2015). Teacher agency, positioning, and English language learners: Voices of pre-service classroom teachers. Teaching and Teacher Education, 45, 94-103.

Kim, B. C. (2003). A qualitative case study on the middle school teachers' cultures of the teaching profession. The Journal of Educational Administration, 21(1), 1-27.

Kim, S. H. (2013a). The rise and development of Korean modern education. Paju: Kyoyookbook.

Kim, Y. M. (2017). A study on the Korean secondary English teachers' perception from a critical approach toward English education. Journal of the Korea English Education Society, 16(2), 37-56. 
Kim, Y. S. (2013b). The relationships between self-directed learning readiness, learning strategies, and achievement: A case of Korean high school English learners. Seoul: Konkuk University.

Korean Ministry of Education. (2015a). 2015 revised English national curriculum.

Korean Ministry of Education. (2015b). 2015 survey for school career education.

Larsen-Freeman, D. (2019). On language learner agency: A complex dynamic systems theory perspective. The Modern Language Journal, 103, 61-79.

Lasky, S. (2005). A sociocultural approach to understanding teacher identity, agency and professional vulnerability in a context of secondary school reform. Teaching and Teacher Education, 21(8), 899-916.

Lee, H. Y. (2006). The status of teacher culture and its developmental direction. The journal of the Korean society for the study of teacher education, 2006, 67-99.

Lee, K. M. (2019). A study on teachers' professionalism and role based on the curriculum reconstruction. Daejeon: Chungnam National University.

Lee, S. B. (2018). A study of middle school English teachers' perception of the free learning semester and alternative assessment. Cheongju: Korea National University of Education.

Lee, S. Y. (2016). The change and issues of 2015 revised English curriculum. Journal of Learner-Centered Curriculum and Instruction, 16(7), 499-519.

Lipponen, L., \& Kumpulainen, K. (2011). Acting as accountable authors: Creating interactional spaces for agency work in teacher education. Teaching and Teacher Education, 27(5), 812-819.

Moate, J. (2014). A narrative account of a teacher community. Teacher Development, 18(3), 384-402.

Moate, J., \& Ruohotie-Lyhty, M. (forthcoming). Identity and agency development in a CLIL-based teacher education Programme. Journal for the Psychology of Language Learning $x, x-x$.

OECD [The Organization for Economic Cooperation and Development]. (2014). TALIS 2013 results: An international perspective on teaching and learning. OECD Publishing Retrieved on 25 June, 2014 from: https://www.oecd.org/education/school/ talis-2013-results.htm.

Pappa, S., Moate, J., Ruohotie-Lyhty, M., \& Eteläpelto, A. (2017). Teacher agency within the Finnish CLIL context: Tensions and resources. International Journal of Bilingual Education and Bilingualism, 65, 61-70.

Priestley, M., Biesta, G., \& Robinson, S. (2015). Teacher agency: An ecological approach. London and New York: Bloomsbury Publishing.

Priestley, M., \& Drew, V. (2019). Professional enquiry: An ecological approach to developing teacher agency. In An ecosystem for research-engaged schools (pp. 154-169). Abingdon and New York: Routledge.

Priestley, M., Edwards, R., Priestley, A., \& Miller, K. (2012). Teacher agency in curriculum making: Agents of change and spaces for manoeuvre. Curriculum Inquiry, 42(2), 191-214.

Rogers, R., \& Wetzel, M. M. (2013). Studying agency in literacy teacher education: A layered approach to positive discourse analysis. Critical Inquiry in Language Studies, 10(1), 62-92.

Ruohotie-Lyhty, M. (2013). Struggling for a professional identity: Two newly qualified language teachers' identity narratives during the first years at work. Teaching and Teacher Education, 30, 120-129.

Ruohotie-Lyhty, M., \& Moate, J. (2015). Proactive and reactive dimensions of life-course agency: Mapping student teachers' language learning experiences. Language and Education, 29(1), 46-61.

Savaya, R., \& Gardner, F. (2012). Critical reflection to identify gaps between espoused theory and theory-in-use. Social Work, $57(2), 145-154$.

Schulzke, M. (2014). The prospects of global English as an inclusive language. Globalizations, 11(2), 225-238.

Song, J. (2016). (II) legitimate language skills and membership: English Teachers' perspectives on early (English) study abroad returnees in EFL classrooms. TESOL Journal, 7(1), 203-226.

Statistics Korea. (2018). The result of the survey on private education cost in 2017.

Sun, D. (2019). Learner agency of immigrant pupils in a Finnish complementary language classroom context. Retrieved from https://jyx.jyu.fi/handle/123456789/64368.

Synott, J. (2007). The Korean teachers and educational workers union: Collective rights as the Agency of Social Change. International Electronic Journal for Leadership in Learning, 11, 23.

Tracy, S. J. (2012). Qualitative research methods: Collecting evidence, crafting analysis, communicating impact. Hoboken: Wiley.

Vähäsantanen, K. (2013). Vocational teachers' professional agency in the stream of change. Jyväskylä studies in education, psychology and social research, (460). Retrieved from https://jyx.jyu.fi/bitstream/handle/123456789/40762/978-951-39-5 054-5.pdf? sequence=2.

Van Lier, L. (2000). From input to affordance: Social-interactive learning from an ecological perspective. In J. Lantolf (Ed.), Sociocultural theory and second language learning (pp. 245-260). New York: Oxford University press.

Van Lier, L. (2004). The ecology and semiotics of language learning. A sociocultural perspective. Boston: Kluwer Academic Publishers.

Van Lier, L. (2008). Agency in the classroom. Sociocultural theory and the teaching of second languages (pp. 163-186). London: Equinox.

Yoo, M. H. (2015). The structural relationship among teachers' self-directed learning ability, basic psychological need, and core competencies of elementary school teachers. Daegu: Daegu National University of Education.

\section{Publisher's Note}

Springer Nature remains neutral with regard to jurisdictional claims in published maps and institutional affiliations. 